\title{
POPULATION FLUCTUATIONS OF OXYCARENUS HYALINIPENNIS AND EFFECT OF CERTAIN COMPOUNDS ON ITS POPULATION ON OKRA IN ASSIUT GOVERNORATE
}

\author{
ABD EL-RAHIM, GAMAL H. ${ }^{1}$ and M. A. AMRO ${ }^{2}$ \\ 1. Horticulture Department, Faculty of Agriculture, El-Azhar University, Assiut, \\ Egypt. \\ 2. Plant Protection Research Institute, ARC, Dokki, Giza, Egypt. \\ Email Address: (moamro1953@yahoo.com)
}

(Manuscript received 25 December 2014)

\begin{abstract}
$\mathrm{P}$ opulation fluctuations of the cotton seed bug Oxycarenus hyalinipennis (Costa) was monitored on okra (Abelmoschus spp.) in Assiut governorate, northern Upper Egypt during 2009 and 2010. In both seasons the pest showed two peaks. The first peak was recorded in the third week of July, while the second one was recorded in mid August. Gradually increase of the pest numbers was detected before each peak and coincided with the increase of the nymphal stage populations. This could be proved that $O$. hyalinipennis may be having two generations on okra planted in northern Upper Egypt. The ability of certain chemical and safe alternative compounds in reducing $O$. hyalinipennis populations in okra dry fruits was determined. The chemical compound Sumithion 50\% EC reduced the pest numbers by $92.21 \%$. However, the tested safe alternative compounds had quietly less effect (ranged from $37.58 \%$ to $80.74 \%$ ). Although the latter compounds ranked the second, they could be used as a promising tool in suppressing $O$. hyalinipennis infestation on okra dry fruits for their acceptable reduction percentage in the pest populations. Furthermore, they can be applied more than one time in one okra growing season.
\end{abstract}

Key words: Oxycarenus hyalinipennis (Costa), chemical and safe alternative compounds, Okra.

\section{INTRODUCTION}

Okra (Abelmoschus spp.) is a traditional vegetable crop with considerable area under cultivation in Africa and Asia with huge socio-economic potential in west and central Africa. It has been called "a perfect villager's vegetable" because of its robust nature, dietary fibers and distinct seed protein balanced in both lysine and tryptophan amino acids. However, okra has been considered a minor crop and no attention was paid to its improvement in the international research program in past (Kumar et al., 2010).

The cotton seed bug Oxycarenus hyalinipennis (Costa) is a serious pest of cotton and other malvaceous plants. It is a relatively widespread species reported to occur on five continents with varying temperature, however, it is typically reported as 
a tropical pest (Henry, 1983). Currently this pest has 40 hosts reported in the literature from the Malvales order. The reported host plants produce seeds at different time of the year, providing potential food source for $O$. hyalinipennis on a continuous bases (Schaefer and Panizzi, 2000). Okra, have also been reported as highly acceptable food source and capable of supporting natural growth to this pest (Dimetry, 1971, Hamed et al., 2010). Both adult and nymph O. hyalinipennis feed on seeds, sucking oil from mature seeds. Cotton seeds for example may appear undamaged but internally the feeding reduces the weight (sometimes up to 15\%) and ultimately renders them unless as they are incapable of developing (Khan and Ahmed, 2000).

Several insecticides have been listed in the literature as effective against $O$. hyalinipennis on cotton, such as: DDT (Ripper and George, 1965), Lindane (Hill, 1983) and Dimethoate (Ikisan, 2004). Also, Neem fruit extracts and seed oil has been demonstrated to be effective against this insect pest on cotton (Khan and Ahmed, 2000).

In Upper Egypt, no attempts have been reported to controlling $O$. hyalinipennis that infest okra plants. This work aimed to monitor the population fluctuation of $O$. hyalinipennis in Assiut governorate and determine the ability of certain chemical and safe alternative compounds in reducing the pest populations in okra dry fruits.

\section{MATERIALS AND METHODS}

This work was carried out in the experimental farm of Al-Azhar University at Assiut region, during the two successive seasons of 2009 and 2010. An area of about $1 / 2$ feddan was cultivated with okra variety "Balady" with replicates $3 \times 3.5$ meter $(1 / 400$ feddan). The cultivated area divided into two equal areas. The first was used to evaluate $\boldsymbol{O}$. hyalinipennis population fluctuations and insecticides were completely prevented. The second was divided into15 replicates (3 replicates /each treatment) in completely randomized block design to determine the potential of the tested compounds in controlling the pest populations. Recommended agronomic practices were performed in all plots included the untreated check.

\section{A- Population fluctuations of $\boldsymbol{O}$. hyalinipennis infesting okra dry fruits:}

Samples were taken weekly from the first area during the first week of July, till the last week of August. Five dry okra fruits were picked up from three replicates in labeled muslin bags and transferred to the laboratory. Samples were kept in refrigerator for 24 hours to preserve 0 . hyalinipennis individuals. Fruits were dissected and numbers of the pest individuals (nymphs + adults) were recorded. 
Percentages of both nymphs and adults were calculated during the entire period of study. This measurement could be enabling to determine the pest generation numbers on okra. Data were statistically analyzed by using f-test, means were compared according to Duncan's multiple range tests as described by Steel and Torrie (1982).

\section{B- The ability of the tested insecticides and other alternative compounds in reducing $O$. hyalinipennis densities:}

The ability of only one spray of the chemical compound (Sumithion $50 \% \mathrm{EC}$ ), the natural compound (Radiant 12\% SC), Neem plant leaf extract (Achook 0.15\%), Jojoba oil seed extract (NAT 1 oil) and the mineral oil (Kemsol) (Table 1) in reducing $O$. hyalinipennis population was tested. Motor spraying was used for applying all the tested compounds in the recommended rates. Five dry okra fruits were picked up from the second area (3 replicates/each compound and the control), transferred to the laboratory in labeled muslin bags, refrigerated for 24 hours and dissected to calculate the pest individuals. Samples were examined before spraying (July 10, 2009 and July 12, 2010) and after one day of the treatment to calculate the initial kill of the tested compounds. The residual effect was measured after 10 days of spraying. General mean reduction was measured throughout $1,3,5,7$ and 10 days post application. All measurements were calculated according to Henderson and Tilton equation (1955).

Table 1. Trade name, common name and application rate of the tested compounds.

\begin{tabular}{|l|c|c|}
\hline \multicolumn{1}{|c|}{ Trade name } & Common name & Application rate \\
\hline 1- Sumithion 50\% EC & $\begin{array}{c}\text { Fenitrothion } \\
\text { (organophosphate) }\end{array}$ & $\begin{array}{c}250 \mathrm{ml} / 100 \\
\text { Liter water }\end{array}$ \\
\hline 2- Radiant $12 \% \mathrm{SC}$ & $\begin{array}{c}\text { Spinotoram } \\
\text { (natural compound) }\end{array}$ & $\begin{array}{c}120 \mathrm{ml} / 100 \\
\text { Liter water }\end{array}$ \\
\hline 3- Achook 0.15\% & Azadirachtin 0.15\% & $100 \mathrm{ml} / 100$ \\
& (neem plant extract) & Liter water \\
\hline 4- NAT 1 oil & Jojoba oil & $1000 \mathrm{ml} / 100$ \\
& Liter water \\
\hline 5- Kemsol oil & Mineral oil & $1000 \mathrm{ml} / 100$ \\
& & Liter water \\
\hline
\end{tabular}




\section{RESULTS AND DISCUSSION}

\section{Population fluctuations of $\boldsymbol{O}$. hyalinipennis infesting okra dry fruits:}

Data presented in Table (2) exhibited the nymphs and adults mean numbers of O. hyalinipennis inhabiting okra dry fruits during 2009 and 2010 growing seasons. Throughout the first year of study (2009) gradually increase of the pest numbers was recorded from the beginning of the season. The first peak of the pest populations was recorded in July 20, with an average of 236 individuals/5 okra dry fruits. Numbers were suddenly decreased in July 27 with an average of 178.8 individuals/5 dry okra fruits. Another gradually increases in the pest numbers was recorded till the appearance of the second peak on August, 17 with an average of 422.5 individuals/5 dry okra fruits. The second peak is equal 1.79 fold the first one.

Similar results were obtained during the second year of study 2010. Note that the second peak is equal 4.24 fold the first one. The obtained results during the entire study period (Table 2 ) revealed that the pest infesting okra fruits from the beginnings of the fruit maturity till harvesting. The pest numbers in 2009 and 2010 seasons increased gradually till July, 20 and presented by 197.2 individuals/5 okra dry fruits. Numbers recorded slightly decrease at the end of July. Then another gradually increase was recorded around mid August whereas the pest showed its highest populations with an average of 546.9 individuals $/ 5$ okra dry fruits. Appearance of two peaks of the pest could be considered as a proof of the incidence of two generations of the pest on okra dry fruits in Assiut region. In this approach Hill (1983) stated that $O$. hyalinipennis may complete anywhere from 3 to 7 generations per year, dependent on temperature and host availability.

Mean percentages of nymphs and adults of $O$. hyalinipennis was recorded in Table (3). Allover the study period, nymphs recorded high percentages than matures. Also, high nymphal incidence was recorded twice, at the first week of both July and August with an average of $69.16 \%$ and $75.68 \%$, respectively. The highest nymph percentages were coincided with the appearance of the gradually increase of the pest numbers which potentially complete up to each peak. In fact, this result prove that $O$. hyalinipennis has two generations at okra in Assiut region. In this respect, reproduction and feeding behavior of the genus Oxycarenus were discussed in details by Samy (1969), Dimetry (1971), Hammad et al. (1972) and Awan and Qurseshi (1996). 


\section{B- The ability of the tested insecticides and other alternative compounds in reducing 0 . hyalinipennis densities:}

Data presented in Tables (4\&5) showed the ability of the tested compounds in suppressing the pest numbers inside the dry okra fruits. It is clear that the highest reduction percentages of the pest numbers were obtained by using the chemical compound and followed by using the safe alternative compounds during 2009 and 2010 growing seasons (Tables 4). After spraying the reduction percentages of the pest numbers decreased gradually by time. One spray could be enough to suppress the pest numbers by using the chemical compound. However, safe alternative compounds could be need more than one application during the okra growing season.

The initial kill, the residual effect and the general reduction percentages caused by using the tested compounds (as an average of two applications) are shown in Table (5). The initial kill of the chemical compound (Sumithion 50\% EC) and the natural compound (Radiant $12 \% \mathrm{SC}$ ) recorded more than $94 \%$ reduction percentages in the pest numbers. However, variable reduction percentages were recorded by using the remaining compounds. In respect to the residual effect, the aforementioned two compounds recorded $82.26 \%$ and $70.55 \%$ reduction on the pest numbers, respectively. Less than $60 \%$ residual effect was recorded by the remaining compounds. The general reduction percentages on the pest numbers showed $92.21 \%$ $>80.74 \%>70.65 \%>62.80 \%>37.58 \%$, for Sumithion $50 \%$ EC, Radiant $12 \%$ SC, Nat 1, Achook $0.15 \%$ and Kemsal oil, respectively.

It is important to note that the chemical compound ranked the first in the ability of suppressing the pest numbers. Although, the tested safe alternative compounds ranked the second and had less effectiveness on the pest densities, they could be used as a promising tool in suppressing $O$. hyalinipennis numbers in okra dry fruits because they had acceptable reduction percentages on the pest numbers except in the case of kemsol oil. Furthermore, they can be applied more one time in one okra growing season to investigate the reduction percentage of the pest densities. In this approach, several insecticides have been listed in the literature as effective against O. hyalinipennis populations eg. Lindane (Hill, 1983), Dimethoate (Ikison, 2001). Also, neem fruit extract and seed oil has been demonstrated to be effective against $O$. hyalinipennis (Khan and Ahmed, 2000). 
Table 2. Mean numbers of $O$. hyalinipennis on okra fruits ${ }^{(a)}$ during 2009 and 2010 growing seasons in Assiut region.

\begin{tabular}{|c|c|c|c|c|}
\hline \multicolumn{2}{|c|}{2009} & \multicolumn{2}{|c|}{2010} & $2009 \& 2010$ \\
\hline Inspection date & $\begin{array}{l}\text { Mean } \\
\pm \mathrm{SD}\end{array}$ & Inspection date & $\begin{array}{l}\text { Mean } \\
\pm \mathrm{SD}\end{array}$ & Mean \\
\hline July, 6 & $\begin{array}{r}87.00 \mathrm{e} \\
\pm 6.58\end{array}$ & July, 7 & $\begin{array}{r}63.50 \mathrm{e} \\
\pm 4.93\end{array}$ & $75.25 \mathrm{C}$ \\
\hline July, 13 & $\begin{array}{l}162.5 \mathrm{~d} \\
\pm 16.36\end{array}$ & July, 14 & $\begin{array}{c}86.25 \mathrm{e} \\
\pm 6.94\end{array}$ & $124.4 \mathrm{D}$ \\
\hline July, 20 & $\begin{array}{l}236.0 \mathrm{~cd} \\
\pm 35.79\end{array}$ & July, 21 & $\begin{array}{l}158.30 \mathrm{~d} \\
\pm 11.90\end{array}$ & $197.2 \mathrm{C}$ \\
\hline July, 27 & $\begin{array}{l}178.8 d \\
\pm 42.50\end{array}$ & July, 28 & $\begin{array}{l}142.50 \mathrm{~d} \\
\pm 12.36\end{array}$ & 160.7 CD \\
\hline August, 3 & $\begin{array}{l}346.3 \text { b } \\
\pm 28.69\end{array}$ & August, 5 & $\begin{array}{r}239.50 \mathrm{c} \\
\pm 9.99\end{array}$ & 292.9 B \\
\hline August, 10 & $\begin{array}{l}357.8 \text { b } \\
\pm 87.30\end{array}$ & August, 11 & $\begin{array}{l}271.3 \mathrm{c} \\
\pm 6.34\end{array}$ & $314.6 \mathrm{~B}$ \\
\hline August, 17 & $\begin{array}{r}422.5 \text { a } \\
\pm 75.55\end{array}$ & August, 18 & $\begin{array}{r}671.3 \text { a } \\
\pm 47.85\end{array}$ & $546.9 \mathrm{~A}$ \\
\hline August, 24 & $\begin{array}{c}280.0 \text { bc } \\
\pm 7.07\end{array}$ & August, 25 & $\begin{array}{l}308.3 \mathrm{~b} \\
\pm 30.09\end{array}$ & 294.2 B \\
\hline F-value & $19.70 * *$ & F-value & $287.9 * *$ & $113.28 * *$ \\
\hline
\end{tabular}

(a) Based on 5 okra dry fruits.

Means followed by the same letter in each column are not significantly different at 0.05 level of probability, by Duncan's multiple range test. 
Table 3. Mean percentages of nymphs and adults of $O$. hyalinipennis on okra fruits during 2009 and 2010 growing seasons in Assiut region.

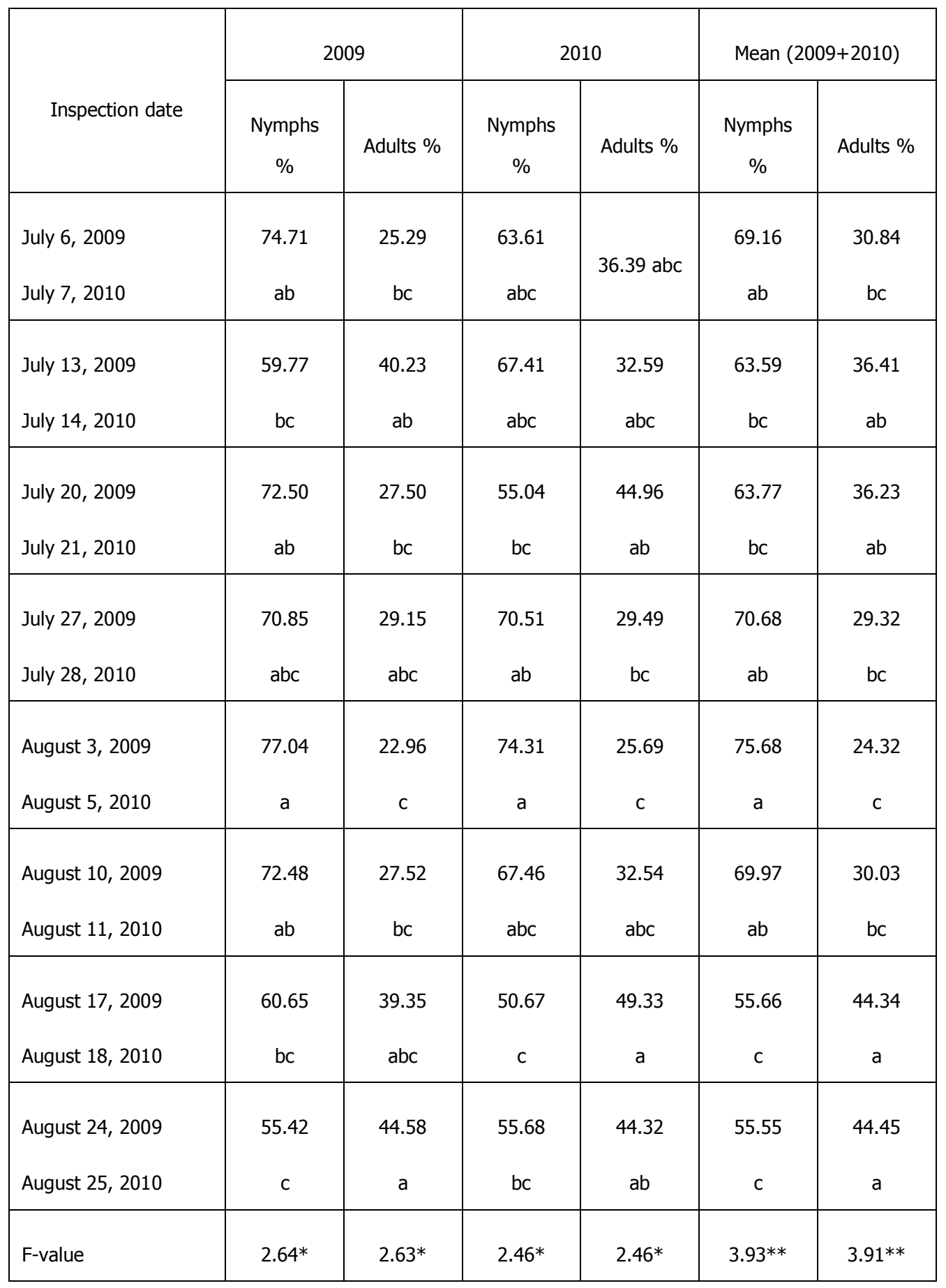

Means followed by the same letter in each column are not significantly different at 0.05 level of probability, by Duncan's multiple range test. 
Table 4. The ability of the tested compounds in reducing $O$. hyalinipennis infestation* during 2009 and 2010 growing seasons in Assiut region.

\begin{tabular}{|c|c|c|c|c|c|c|c|c|c|c|c|c|c|c|}
\hline \multirow{3}{*}{ Compound } & \multirow{2}{*}{\multicolumn{2}{|c|}{$\begin{array}{c}\text { Mean numbers of } O \text {. } \\
\text { hyalinipennis } \\
\text { (nymphs + adults) } \\
\text { before spraying }\end{array}$}} & \multicolumn{10}{|c|}{ Reduction $\%$ after } & \multirow{2}{*}{\multicolumn{2}{|c|}{$\begin{array}{c}\text { General reduction } \\
\%\end{array}$}} \\
\hline & & & \multicolumn{2}{|c|}{ One day } & \multicolumn{2}{|c|}{3 days } & \multicolumn{2}{|c|}{5 days } & \multicolumn{2}{|c|}{7 days } & \multicolumn{2}{|c|}{10 days } & & \\
\hline & 2009 & 2010 & 2009 & 2010 & 2009 & 2010 & 2009 & 2010 & 2009 & 2010 & 2009 & 2010 & 2009 & 2010 \\
\hline Sumithion $50 \% \mathrm{EC}$ & 100.7 & 94.67 & 99.88 & 98.42 & 93.04 & 95.41 & 93.42 & 94.15 & 92.00 & 94.26 & 84.36 & 80.16 & 91.94 & 92.48 \\
\hline Radiant $12 \%$ SC & 98.67 & 92.00 & 93.76 & 95.26 & 93.62 & 94.39 & 72.59 & 75.70 & 72.40 & 68.43 & 72.46 & 68.64 & 80.99 & 80.48 \\
\hline Achook $0.15 \%$ & 99.67 & 102.6 & 82.06 & 77.09 & 68.68 & 77.05 & 51.59 & 59.05 & 53.20 & 52.85 & 53.76 & 52.64 & 61.86 & 63.74 \\
\hline NAT 1 & 99.33 & 99.66 & 83.62 & 80.25 & 79.12 & 79.09 & 72.27 & 74.80 & 60.40 & 58.59 & 59.88 & 58.40 & 71.06 & 70.23 \\
\hline Kemsol oil & 96.67 & 92.33 & 30.58 & 29.69 & 14.74 & 27.58 & 42.19 & 43.30 & 44.00 & 42.19 & 47.98 & 53.60 & 35.89 & 39.27 \\
\hline Control & 102.3 & 95.33 & -- & -- & -- & -- & -- & -- & -- & -- & -- & -- & -- & -- \\
\hline
\end{tabular}

*Based on 5 okra dry fruits. 
Table 5. Initial kill, residual effect and general reduction percentages of the tested compounds against $O$. hyalinipennis infestation (a) during 2009 and 2010 growing seasons in Assiut region.

\begin{tabular}{|c|c|c|c|c|c|c|c|c|c|}
\hline \multirow{2}{*}{ Compound } & \multicolumn{3}{|c|}{ Initial kill \% } & \multicolumn{3}{|c|}{ Residual effect \% } & \multicolumn{3}{|c|}{ General reduction \% } \\
\hline & 2009 & 2010 & Mean & 2009 & 2010 & Mean & 2009 & 2010 & Mean \\
\hline Sumithion $50 \%$ EC & 96.88 & 98.42 & 97.65 & 84.36 & 80.16 & 82.26 & 91.94 & 92.48 & 92.21 \\
\hline Radiant $12 \%$ SC & 93.76 & 95.26 & 94.51 & 72.46 & 68.64 & 70.55 & 80.99 & 80.48 & 80.74 \\
\hline Achook $0.15 \%$ & 82.06 & 77.09 & 79.58 & 53.76 & 52.64 & 53.20 & 61.86 & 63.74 & 62.80 \\
\hline NAT 1 & 83.62 & 80.25 & 81.94 & 59.88 & 58.40 & 59.14 & 71.06 & 70.23 & 70.65 \\
\hline Kemsol oil & 30.58 & 29.69 & 30.14 & 47.98 & 53.60 & 50.79 & 35.89 & 39.27 & 37.58 \\
\hline
\end{tabular}

(a) Based on 5 okra dry fruits. 


\section{REFERENCES}

1. Awan, M.S. and Qurseshi. 1996. Study of biological parameters of dusky cotton bug, Oxycarenus loetus (Sic.) Kirby (Lygaeidae: Heteroptera) in Sindh. Proc. Pakistan Congr. Zool., 16: 265-268.

2. Dimetry, N.Z. 1971. Studies on the host preference of the cotton seed bug Oxycarenus hyalinipennis Costa (Hemiptera: Lygaeidae). Z. Ang. Ent. 68 (1): 63-67.

3. Hamed, H.H., Afsah, A.F.E. and Husein, H.H. 2010. Improvement quality and quantity of okra seed yield (Abelmoschus esculentus L.) through control of cotton seed bug (Oxycarenus hyalinipennis Costa). Fayoum J. Agric. Res. \& Dev. 24 (1): 84-90.

4. Hammad, S.M., Armanius, N. and El-Deeb A.A. 1972. Some biological aspects of Oxycarenus hyalinipennis Costa (Hemiptera: Lygaeidae). Bull. Soc. Ent. Egypt, 56: 33-38.

5. Henderson, C.F. and Tilton, E.W. 1955. Tests with acaricides against the brown wheat mite. J. Econ. Entomol., 48: 157-161.

6. Henry, T.J. 1983. Pests not known to occur in the United states or of limited distribution. USDA-APHIS-PPQ. Aphis 81-43: 1-6.

7. Hill, D.S. 1983. Agricultural Insect Pests of the tropics and their control. Cambridge, Cambridge University Press.

8. Ikisan, 2004. Cotton insect management. Retrieved 04/06/06, 2006, from http://www.ikisan.com/links/knt-cotton insect\% 20 Management.shtml.

9. Khan, M.F. and Ahmed, S.M. 2000. Toxicity of neem fruit extract and seed oil against Oxycarenus (Heteroptera) of cotton crop. Acta Biol. Cracoviensia Series Zool. 42: 14-21.

10. Kumar, S., Dagnoko, S., Haougui, A., Ratnadas, A., Pasternak, D. and Kouame, C. 2010. Okra (Abelmoschus spp.) in west and central Africa. Potential and Progress on its improvement. African J. Agric. Res. 5 (25): 3590-3598.

11. Ripper, W.E. and George, L. 1965. Cotton pests of the Sudan: Their habits and control. Oxford, Blackwell Scientific Publications.

12. Samy, O. 1969. A revision of the African species of Oxycarenus (Hemiptera: Lygaeidae). Trans. R. Entomol. Soc. London, 121: 79-165.

13. Schaefer, C.W. and Panizzi, A.R. 2000. A Heteroptera of economic importance. Boca Raton, CRC Press.

14. Steel, R.G.D. and Torrie, J.H. 1982. Principles and Procedures of Statistics. A Biometrical Approach, McGraw-Hill Book Co. 


\section{تذبذب أعداد بق بذرة القطن ومقدرة بعض المركبات علي خفض مجاميعها علي الباميا بمحافظة أسيوط}

جمال حسين عبد الرحيم'و محمد عبدالرحمن محمد عمرو`

$$
\begin{aligned}
& \text { ا ـ قسم البساتين - كلبة الزراعة - جامعة الأزهر بأسيوط } \\
& \text { r ـ معهُ بحوث وقاية النباتات - مركز البحوث الزراعية - الدقى - الجيزة. }
\end{aligned}
$$

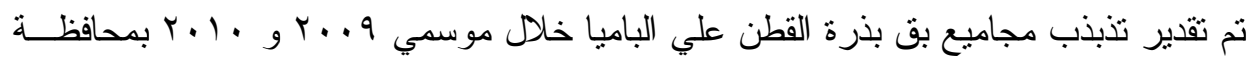

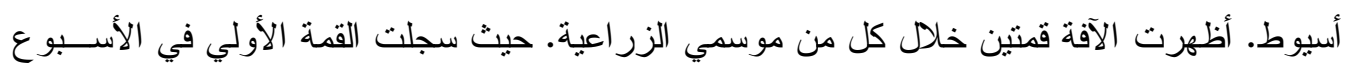

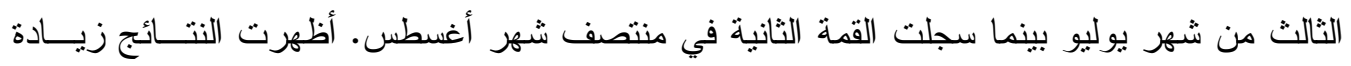
تدريجية في أعداد الآفة قبل كل قمة و التي تز امنت مع الزيادة في تو اجد الحوريات. وقد يستدل مــن فئن

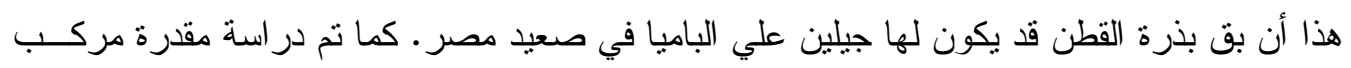

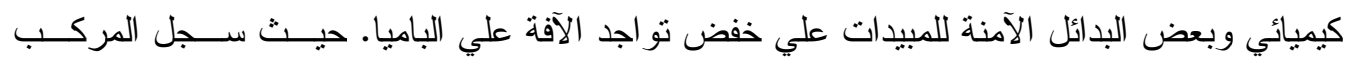

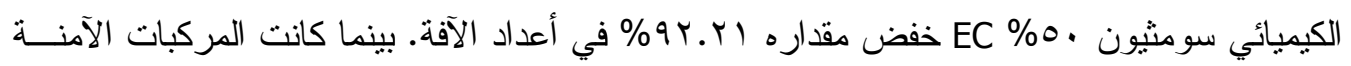

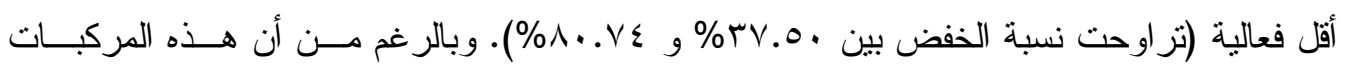

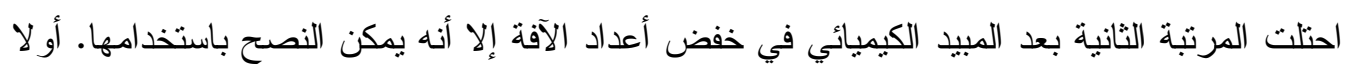

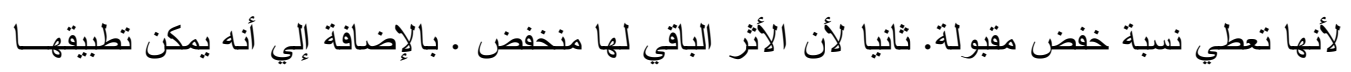

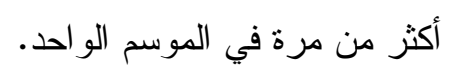

